\title{
SOVEREIGNTY AS A MOTOR OF GLOBAL CONCEPTUAL TRAVEL: SANSKRITIC EQUIVALENTS OF “LAW" IN BENGALI DISCURSIVE PRODUCTION
}

\author{
MILINDA BANERJEE
}

Ludwig-Maximilians-Universität München/Presidency University Kolkata

E-mail: milindabanerjee1@gmail.com

\begin{abstract}
How may one imagine the global travel of legal concepts, thinking through models of diffusion and translation, as well as through obstruction, negation, and dialectical transfiguration? This article offers some reflections by interrogating discourses (intertextually woven with Sanskritic invocations) produced by three celebrated Bengalis: the nationalist litterateur Bankimchandra Chattopadhyay (1838-94), the Rajavamshi "lower-caste" peasant leader Panchanan Barma (1866-1935), and the international jurist Radhabinod Pal (1886-1967). These actors evidently took part in projects of vernacularizing (and thereby globalizing through linguistic-conceptual translation) legal-political frameworks of state sovereignty. They produced ideas of nexus between sovereignty, law, and "divine" lawgiving activity, which resemble as well as diverge from notions of political theology associated with the German jurist Carl Schmitt. Simultaneously, these actors critiqued coercive impositions of state-backed positive law and sovereign violence, often in the name of globally oriented concepts of "ethical"/natural law, theology, and capacious forms of solidarity, including categories like "all beings," "self/soul," "humanity," and "world." I argue that "sovereignty," as a metonym for concrete practices of power as well as a polyvalent conceptual signifier, thus dialectically provoked the globalization of modern legal intellection, including in the extra-European world.
\end{abstract}

\section{INTRODUCTION}

How may one imagine the global travel of legal concepts, thinking through as well as going beyond models of diffusion and translation, and taking into account obstruction, negation, and dialectical transfiguration? How can one think of variant definitions of the "global" by taking into account macroprocesses and structural frameworks that operate at a planetary scale (and offer one rationale for adopting a globally oriented scale of analysis), while retaining sensitivity to the contingent choices and agencies of local actors that 
defy overdetermination? To reflect on these questions in the emergent field of global intellectual history, this article interrogates arguments produced by three celebrated Bengali actors (even while abjuring any ambition to offer comprehensive reviews of Bengali perceptions of law): the Indian nationalist littérateur Bankimchandra Chattopadhyay (1838-94), the leader of the powerful Rajavamshi peasant caste movement Panchanan Barma (1866-1935), and the international jurist Radhabinod Pal (1886-1967). Besides possessing Western legal training, these individuals were also well versed in precolonial Sanskritic legalmoral concepts and texts. They embodied influential legally inflected perspectives on anticolonial nationalism and/or subaltern politics. While being part of wider trajectories of decolonization and democratization in India, their arguments configured, from the margins of the imperial world, new and defiant definitions of the global.

I argue that a focus on the globally entangled production and dissemination of modern structures and concepts of state sovereignty can help us to locate one very important motor of globally oriented intellection. ${ }^{1}$ The planetary spread of capitalism has been identified by Andrew Sartori as a principal determining factor in globalizing intellection, ensuring a constitutive bivalence to intellectual labor, such that a local discourse-for example about culture or freedomwould also be structurally global through its enracination in a field of capitalist production. ${ }^{2}$ In a comparable manner, I suggest that every act of modern political-legal intellection, however regional in scale, can be seen as having been simultaneously part of a global discourse to the extent that no political actor positioned anywhere in the late nineteenth- and early to mid-twentieth-century world could ignore the globally expansive experience of sovereign statehood while formulating their discourses, whether they did so in order to resist coercive impositions of state power-sometimes in the name of a universalistic and globalizable order of law and justice-or to assert varying claims of authority within the conceptual and structural limits of state sovereignty. (Often, the two postures were braided together.) It becomes imperative, therefore, to explain this sort of political-legal intellection through globally inflected categories and scales of analysis. The globality of modern political-legal intellection (but by

I use the imagery of "motor" in a heuristic way, and not as an all-encompassing explanation for change. Christopher Bayly has criticized deterministic attempts to locate "prime movers" behind global historical change, but deploys the image of "motors of change": C. A. Bayly, The Birth of the Modern World, 1780-1914: Global Connections and Comparisons (Malden, 2004), 5-8, 473-5.

2 Andrew Sartori, Bengal in Global Concept History: Culturalism in the Age of Capital (Chicago, 2008); Sartori, "Global Intellectual History and the History of Political Economy," in Samuel Moyn and Andrew Sartori, eds., Global Intellectual History (New York, 2013), 110-33; Sartori, Liberalism in Empire: An Alternative History (Oakland, 2014). 
no means only of modern intellection) is linked to the unending-and, by now, planet-spanning - proliferation of schemes of discrimination, between insiders and outsiders, friends and enemies, with respect to structures of sovereign power, and especially, but not exclusively, state power, ${ }^{3}$ as well as to the disruption, if not partial dismantling, of these hierarchies through political strategies of solidarity building and resistance, which are also often framed through transregionally oriented conceptual labor.

There are significant intellectual histories of perceptions of law in colonial Bengal. ${ }^{4}$ Similarly, there are sophisticated works on transformations in Hindu law across the colonial divide. ${ }^{5}$ This article opens up another perspective by using the concept of political theology advanced by the controversial German jurist Carl Schmitt (1888-1985) to interpret specific cases in which Bengali actors juxtaposed in their writings citations of English-language legal terms with theologically inflected Sanskritic ones and thereby sought to establish semantic translatability and equivalence between them. In his book Political Theology (1922), Schmitt famously noted, "All significant concepts of the modern theory of the state are secularized theological concepts not only because of their historical development-in which they were transferred from theology to the theory of the state, whereby, for example, the omnipotent God became the omnipotent lawgiver-but also because of their systematic structure." ${ }^{6}$ This insight, linking structures and concepts of modern state law and sovereignty to theological categories, has been built upon by others, such as Giorgio Agamben, ${ }^{7}$ Robert Yelle, ${ }^{8}$ and Peter Fitzpatrick (who draws on Schmitt to outline a domain of legal theology). ${ }^{9}$ As the editors of a recent volume suggest, "Law, thought to be one of the exemplary domains of secularism, instead emerges as a signal location in which the sacred has resided and continues

3 I draw here on Carl Schmitt, The Concept of the Political (Chicago, 2007; first published 1927, 1932); and more idiosyncratically, on Schmitt, The Nomos of the Earth: In the International Law of the Jus Publicum Europaeum (New York, 2003; first published 1950, 1974).

4 E.g., Anindita Mukhopadhyay, Behind the Mask: The Cultural Definition of the Legal Subject in Colonial Bengal (1715-1911) (Delhi, 2006); Mithi Mukherjee, India in the Shadows of Empire: A Legal and Political History, 1774-1950 (Delhi, 2010).

5 For a recent historiographic overview see Timothy Lubin, Donald R. Davis Jr, and Jayanth K. Krishnan, eds., Hinduism and Law: An Introduction (Cambridge, 2010).

6 Carl Schmitt, Political Theology: Four Chapters on the Concept of Sovereignty (Cambridge, MA, 1985), 36.

7 Giorgio Agamben, The Kingdom and the Glory: For a Theological Genealogy of Economy and Government (Stanford, 2011).

8 Robert A. Yelle, The Language of Disenchantment: Protestant Literalism and Colonial Discourse in British India (New York, 2013).

9 Peter Fitzpatrick, "Legal Theology: Law, Modernity and the Sacred," Seattle University Law Review 32/2 (2008), 321-41. 
to reside alongside and as a fundamental part of the secular." 10 To think about this relation beyond area-studies frames (beyond specific histories of European discourse, Hindu law, and the like) is a challenge this article takes up. I do not thereby intend to validate Schmitt's particular claims about the theological foundations of legal-political ideas: such notions demand critical inspection, careful historicization, and perhaps even bracketing, especially keeping in mind Schmitt's support for authoritarian (and eventually Nazi) decisionist politics in interwar Germany. However, such arguments do help us to comparatively locate Bengali actors who toyed with, and also challenged, similar perspectives.

How does one envisage legal concepts in global intellectual history? Postcolonially inflected approaches have demonstrated how colonial encounters have had major constitutive effects on modern formations of law, as in configurations of state sovereignty, property, and customs. ${ }^{11}$ Various scholars have highlighted the multisited and entangled — and, in this sense, globalizedemergence of modern concepts of legal internationalism, human rights, and international criminal justice. ${ }^{12}$ The role of extra-European actors in transforming legal intellection has received specific attention. Sartori, for example, has shown the valence of legally inflected discourses on property and labor for Muslim peasant conceptions of autonomy in colonial Bengal, ${ }^{13}$ while Arnulf Becker Lorca focuses on the contributions of late nineteenthand early twentieth-century non-European lawyers to the emergence of modern international law. ${ }^{14}$

Lorca regards the field of international law as Western-dominated in its genesis and in its linguistic-conceptual register. He uses the term "mestizo international law" to think about "the paternal Western tradition" that "the mixed child"

10 Martha Merrill Umphrey, Austin Sarat, and Lawrence Douglas, "The Sacred in Law: An Introduction," in Austin Sarat, Lawrence Douglas, and Martha Merrill Umphrey, eds., Law and the Sacred (Stanford, 2007), 1-27, at 20. See also Winnifred Fallers Sullivan, Robert A. Yelle, and Mateo Taussig-Rubbo, eds., After Secular Law (Stanford, 2011).

11 E.g. Antony Anghie, Imperialism, Sovereignty and the Making of International Law (Cambridge, 2004); Lauren Benton, A Search for Sovereignty: Law and Geography in European Empires, 1400-1900 (New York, 2010); Karuna Mantena, Alibis of Empire: Henry Maine and the Ends of Liberal Imperialism (Princeton, 2010); Andrew Fitzmaurice, Sovereignty, Property and Empire, 1500-200o (Cambridge, 2014).

12 E.g. Martti Koskenniemi, The Gentle Civilizer of Nations: The Rise and Fall of International Law, 1870-1960 (Cambridge, 2004); Samuel Moyn, The Last Utopia: Human Rights in History (Cambridge, MA, 2010); David M. Crowe, War Crimes, Genocide, and Justice: A Global History (New York, 2014).

13 Sartori, Liberalism in Empire.

14 Arnulf Becker Lorca, Mestizo International Law: A Global Intellectual History, 1842-1933 (Cambridge, 2014). 
cannot ignore, rendering impossible a "return" to the "indigenous mother." $\mathrm{He}$ argues that "international law became an order of global geographical scope throughout the appropriation of the European legal tradition by non-Western jurists." 15 This article pursues a different agenda by focusing on legal-theological discourses whose linguistic-conceptual registers were not entirely structured by "the West" (however capaciously and indeterminately the latter is conceived). I respond to Samuel Moyn, who has invited global intellectual historians to go beyond models of truncated universalism in which the role of non-European actors becomes reduced to fulfilling (if only through contestation) conceptual frameworks of essentially European provenance. ${ }^{16} \mathrm{I}$ am interested in transversal interventions that cut across (constructed) cultural and temporal frontiers by forging semantic equivalences. The density of citation of precolonial Sanskritic concepts and texts in some of the works I study indeed provokes us to think of notions of the global in terms of making proximate and dialogic not just spatially, but also temporally, distanced locations. ${ }^{17}$ Simultaneously, as Shruti Kapila reminds us, we need to bear in mind the ruptures and discontinuities from past traditions of thinking while reflecting on what propels constructions of the global in modern intellectual history. ${ }^{18}$

This article's empirical focus on "Sanskritic" discourses does not imply that the kind of intellectual production discussed here was provincially hinged to precolonial-origin "Indic" classical worldviews, or, in social terms, monopolized by high-caste Hindu elites. Of the three actors studied here, only Bankimchandra Chattopadhyay, a Bengali Brahmin, can be classified in the latter category. Panchanan Barma and Radhabinod Pal came from communities regarded as "low-caste" by Brahmanical elites. Moreover, the anxieties about sovereignty and sovereign violence exhibited by these intellectuals were shown in equal measure by Indian actors of non-Hindu origin, such as the anticolonial militant Muhammad Ali (1878-1931) and the celebrated poet-rebel Kazi Nazrul Islam (1899-1976). These two actors battled the British colonial state, including in the course, or the aftermath, of court trials in the early 1920s, by denouncing state (or, in their eyes, human) sovereignty, law, and state-directed violence, in the name of allegedly

\footnotetext{
15 Ibid., 22-3.

16 Samuel Moyn, "On the Nonglobalization of Ideas," in Moyn and Sartori, Global Intellectual History, 187-204.

17 Discussions on transtemporality, as advanced in David Armitage, "What's the Big Idea? Intellectual History and the Longue Durée," History of European Ideas 38/4 (2012), 493-507, are relevant here.

18 Shruti Kapila, "Global Intellectual History and the Indian Political," in Darrin M. McMahon and Samuel Moyn, eds., Rethinking Modern European Intellectual History (New York, 2014), 253-74.
} 
higher divine legal norms and ethics of humanity and non-killing. ${ }^{19}$ I argue that such anxieties about sovereignty should be seen as functions of the global spread of regimes of state sovereignty and violence across the nineteenth and twentieth centuries, rather than as the exclusive and unconnected manifestations of regional or sectarian cultural formations. Hence, global intellectual history offers innovative analytical tools to study these standpoints.

\section{BANKIMCHANDRA CHATTOPADHYAY AND THE EMERGENCE OF AN INDIAN NATIONALIST THEOLOGY OF LAW}

The essayist and novelist Bankimchandra Chattopadhyay is often considered nineteenth-century India's most famous littérateur. ${ }^{20}$ He inherited a Brahmin family tradition of Sanskrit education, which was augmented through contact with Sanskrit scholars of the famous town of Bhatpara. After receiving a Westernstyle school education, ${ }^{21}$ he was admitted in 1856 to Presidency College, colonial Calcutta's premier centre for European-type higher education, to study law. In 1858 he became one of the first Indians to receive a BA degree from the newly instituted University of Calcutta, and was soon appointed a deputy magistrate. In 1869 he completed his legal training. He remained a member of the Bengal civil service until 1891 . $^{22}$

We may begin examining Bankimchandra's outlook on law through his satirical piece "Kamalakanter Jobanbandi" (Kamalakanta's Testimony) (1885). Here the eponymous hero publicly_-in a court and among a crowd-defended a thief's right to a stolen cow on the ground that according to the "international law" of Europe, the "right of conquest" was a valid "right" which had enabled countries exercising it to become sabhya (civilized) and unnata (progressive/developed) by plundering the prithivi (earth). Kamalakanta observed that, by this logic, the "right of theft" was also a "right" according to ain (the Persian-origin word used to denote ordinary positive law rather than any higher sacral-moral law). ${ }^{23}$ The

19 Milinda Banerjee, The Mortal God: Imagining the Sovereign in Colonial India (Delhi, 2018), chap. 5 .

20 Bankimchandra has been well researched by historians and literary scholars (including from the aspect of legal-cultural history, as in Mukhopadhyay, Behind the Mask). But to the best of my knowledge he has never been studied through a Schmittian approach of political-legal theology. For reason of space, I have not analyzed his novels here.

${ }_{21}$ Julius J. Lipner, "Introduction," in Bankimcandra Chatterji, Anandamath, or The Sacred Brotherhood (New York, 2005), 10-12.

22 C. E. Buckland, Dictionary of Indian Biography (London, 1906), 79-80; Anjali Bose, Samsad Bangali Charitabhidhan (Calcutta, 2013), 446.

23 Bankimchandra Chattopadhyay, Bankim Rachanavali, vol. 2, ed. Jogesh Chandra Bagal (Calcutta, 1994), 95. Across this essay, I transliterate $r$ as $r i$ (following Radhabinod Pal). 
sketch, equating Western legal ideas of colonial occupation with outright theft, needs to be seen in relation to Bankimchandra's previous years of criticism against the racism, corruption, and oppression of the poor inherent in the colonial legal system in India. He was equally scathing in condemning the brutalities of caste discrimination in Hindu law. ${ }^{24}$ The Berlin Conference (1884-5), the scramble for Africa, and the inauguration of a new wave of European imperialism formed the broader historical backdrop for this satire.

Across the 188 os, in reaction to European colonialism and the aggressive spread of regimes of state sovereignty, Bankimchandra would fashion an alternative Sanskrit-derived Bengali vocabulary of legal-theological sovereignty in several long essays. In Krishnacharitra (Character of Krishna) $(1875,1886,1892$ ), he argued that what Europeans termed "law" was understood by the poets of the ancient Indian epic Mahabharata as ishvarechchha (divine will) or ishvaraprerana (divine inspiration); this stood above "law" and was the source of "law." The divine hero of the Mahabharata, Krishna, had functionalized this legality. ${ }^{25}$ After waging wars to unify India, which Bankimchandra implicitly compared with the nineteenth-century unification of Italy and Germany, Krishna, who was compared to Cavour and Bismarck, ${ }^{26}$ established Yudhishthira as king, and made the dying warrior prince Bhishma his mouthpiece to institute a system of "legislation" or vidhivyavastha. Supposedly, Krishna knew that for samsthapan (institution/establishment) and raksha (protection) of a dharmarajya (kingdom/polity of dharma), a dharmik (righteous) king would not suffice; dharmanumata vyavastha vidhibaddha, codification of a dharma-oriented system of legality, was necessary. Accordingly, Bhishma lectured on dharma, including on rajadharma, the ruler's dharma. ${ }^{27}$ The Hindu-Indian nation-state was imagined through the concept of a (somewhat Schmittian) divine lawgiver's will and of a resultant divinely inspired legislative order: not coincidentally, Bankimchandra compared Krishna with Jeremy Bentham, the British proponent of legal reform and codification. ${ }^{28}$ For Bankimchandra, the shantiparva (episode of peace) of the Mahabharata functioned as the constituent moment when the Indian nation's juridical being had taken shape in the (legendary) past: it served as a template for the future freedom of an unfree nation.

This foundational legality had a cosmological dimension. In Dharmatattva (Discourse on Dharma) (1888) Bankimchandra equated the "law" of the

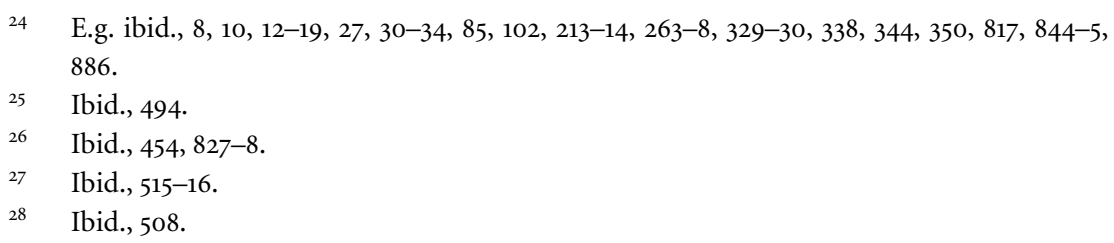


scientists with divinity. ${ }^{29}$ In Shrimadbhagavadgita (1886-9) he argued that the modern scientific concept of "law" or niyama was rooted in the karma (action) of ishvara (divinity). ${ }^{30}$ For Bankimchandra, the Indian divine was based on niyama/law, manifested in the causality-based law of karma and reincarnation, whereas the Christian God acted through "miracle" to send people to heaven or hell, as a (somewhat arbitrary) judge took recourse to judicial "decree" and "dismiss." ${ }^{11}$ His Devatattva o Hindudharma (Discourse on Divinity and Hinduism) (posthumously published) elaborated that the Hindu belief in a singular divine niyamakarta (lord of law) was embedded in the observation that underlying all natural phenomena was one niyama (law).32

In these final essays of his life, Bankimchandra conceptualized the Christian God as a German- or Russian-style monarch who was distinct from his subjects and constantly policed them. Contrastively, the Indian divinity was supposedly immanent in all creatures. ${ }^{33}$ Bankimchandra built his global/universalistic categories through intertextual references to precolonial Indic texts, especially the Vajasaneyi Samhita Upanishad (Isha Upanishad), the Gita, the Vishnu Purana, and the Bhagavata Purana (all composed between the middle of the first millennium $\mathrm{BCE}$ and the end of the first millennium $\mathrm{CE}$, but in popular circulation in colonial Bengal). This form of exegesis reminds one of-although there are also obvious differences with-the early nineteenthcentury exercises of the Bengali reformer Rammohun Roy (1772/4-1833), and indeed of centuries-old polyglot debates in precolonial Indian worlds about the relation between social stratification and ethical-social universalism. It is necessary to locate Bankimchandra within longer South Asian traditions of framing ethics through universalistic categories; however, his explicit references to European legal and philosophical-theological concepts differentiate him from his precolonial predecessors, who operated through more (geographically) regional vocabularies. ${ }^{34}$ Adopting Sanskrit discursive frames, Bankimchandra described the divine through terms like sarvabhutamaya (immanent in all beings) and sarvabhuter antaratma (the inner soul/self of all beings). Hence the highest dharma/law was to will, through nishkama karma (desireless action), the good of

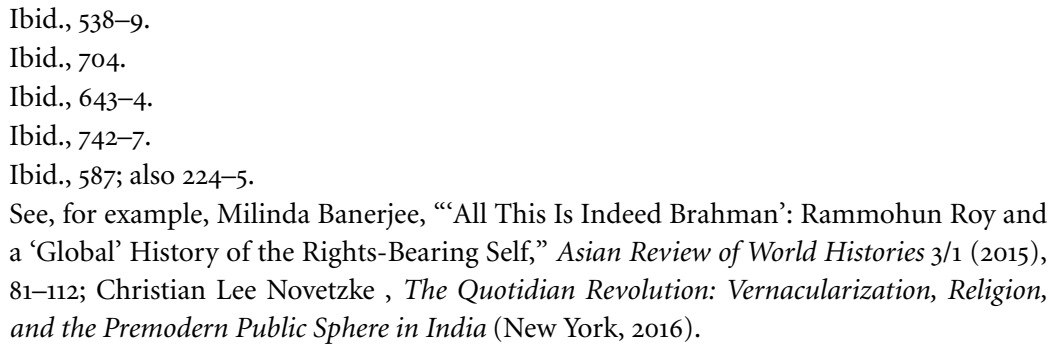
a 'Global' History of the Rights-Bearing Self," Asian Review of World Histories 3/1 (2015), 81-112; Christian Lee Novetzke, The Quotidian Revolution: Vernacularization, Religion, and the Premodern Public Sphere in India (New York, 2016). 
sarvaloka (all beings), including those not of one's community or nation, as well as nonhumans. To enable freedom and merit to flourish regardless of inherited status, class, and biology, Bankimchandra tried to frame varna-jati (caste) and gender roles in Hindu legal-moral discourse according to liberal principles. ${ }^{35}$ To produce a universalistic category of ethical subjectivity, he translated Auguste Comte's notion of "humanity" into the Bengali manushyatva. As evident in various writings of his, dating from the 1870 s onward, Bankimchandra was also inspired by Christian ideals of universal brotherhood, by Rousseau's concepts of equality and social contract, by the French Revolution, by Utilitarian notions of maximizing the well-being of the greatest number of people, and by variants of French socialism. ${ }^{36}$

Bankimchandra was, however, also responsible for producing a rabidly nationalistic discourse. He argued that Europeans exhibited a sinful "patriotism," which led them to wage brutal wars, and to exterminate entire populations like the Native Americans. He castigated the colonization of Poland, Egypt, and Vietnam, and the violence of intra-European warfare, such as between France and Germany. He urged Indians, and indeed people of every country, to defend themselves, if necessary through dharmayuddha (righteous/just war), from imperialist conquerors, of which European and Muslim invaders were, for him, the paramount exemplars. Hence universal love had to be tempered with love for the native country (svadesha) and national legal-moral order (svadharma), instantiated through the sovereign nation-state, imagined as a dharmarajya. By the 1880 s, this nationalist impetus led Bankimchandra to praise the supposedly nation-building virtues of (reformed) caste order and patriarchy, and to advance racialized notions of Hindu civilizational superiority against not only Christians and Muslims, but also Native Americans, Africans, Polynesians, and Australian aborigines. ${ }^{37}$ We observe in other Bengali Hindu and Muslim authors, including Girishchandra Ghosh (1844-1912), Nabinchandra Sen (1847-1909), Mir Mosharraf Hossain (1847-1912), and Kaikobad (18581952), comparable framings of dharma(rajya). ${ }^{38}$ In such discourses, dharma embodied, often with dialectically productive contradiction, the aspiration for legally framed sectarian-national sovereignty, as well as the hope to transcend the nation through wider solidarities (in the case of Bankimchandra, through the production of categories like "humanity" and "all beings," as

\footnotetext{
35 Chattopadhyay, Bankim Rachanavali, 508, 535, 557-8, 572-602, 630, 703-4.

36 Ibid., 331-51, 506, 531, 558, 586, 591-3.

37 Ibid., 438, 452, 475-6, 503, 531, 548-9, 555-9, 564-5, 586-7, 597-8, 628-31, 694, 706, 730-34, 743.

38 Banerjee, The Mortal God, chap. 3.
} 
well as through references to the plight of the colonized in regions beyond South Asia).

\section{PANCHANAN BARMA, DHARMA, AND DEMOCRATIZATION}

This section focuses on the most iconic figure of the Rajavamshi movement, Panchanan Barma. The Rajavamshis (literally, "people of the royal lineage") emerged out of a wide spectrum of peasant groups associated with late precolonial state formation in sub-Himalayan Bengal and Assam. From the nineteenth century, colonial fiscal, administrative, and military interventions, aided by immigrant (often Western-educated) high-caste Hindu Bengali gentry, contributed to diminishing the landholding and political powers of the peasantry in British-ruled northern Bengal and the adjacent princely state of Cooch Behar. The chief Indian beneficiaries of these processes were the immigrant highcaste Hindu gentry who denigrated the local peasants as primitive low-castes. From 1910, the Kshatriya Samiti was the principal association through which the Rajavamshis retaliated. The Samiti advanced a regal Kshatriya identity for Rajavamshis; promoted literacy, healthcare, and business ventures among them; and pressured the state for reservations and other welfare measures in legislative representation, education, and employment. From the 1930s, Rajavamshis were categorized as a scheduled caste and entitled to legally enshrined reservations; their rise is part of a pan-Indian twentieth-century ascendancy of lowercaste/Dalit politics. ${ }^{39}$

Born in Cooch Behar to a family of rural peasant origin, Barma received Western school education, got university degrees in Sanskrit and law in the 1890s, and practiced as a lawyer in northern Bengal in the 1900s, before heading the Kshatriya Samiti. A member of the Bengal Legislative Council across the 1920 s and early 1930s, he worked for legislative measures (especially reservations) and other forms of state support for the lower castes and peasants. ${ }^{40}$ The politicaltheological significance that he attributed to legality in this regard is visible in a letter (preserved in both English and Bengali versions) that he sent on behalf of the Samiti to the chief secretary to the government of Bengal in November 1917, asking to meet the visiting Secretary of State for India, Edwin Montagu. The British wartime promise, emblematized by Montagu's declaration of August 1917,

39 Ibid., chap. 4; Swaraj Basu, Dynamics of a Caste Movement: The Rajbansis of North Bengal, 1910-1947 (Delhi, 2003); Sukhbilas Barma, Indomitable Panchanan: An Objective Study on Rai Sahib Panchanan Barma (Delhi, 2017).

40 Banerjee, Mortal God, chap. 4, Basu, Dynamics of a Caste Movement; and Barma, Indomitable Panchanan; Upendranath Barman, Thakur Panchanan Barmar Jivanacharita (Jalpaiguri, 1980), 1-16, 60-78. 
to ensure "self-governing institutions" and "responsible government" in India (which would culminate in the Government of India Act of 1919, expanding electoral-legislative powers of Indians), ${ }^{41}$ was the instigation. ${ }^{42}$

Appropriating the British concept of "self-governing institutions" and hybridizing it with Rajavamshi structures and notions of communitarian rule, Barma outlined that the "Kshatriya community"/kshatriyasamaj, as a part of "Hindu society"/hindusamaj, had traditionally been

internally governed by small Samajas or Societies each with its controlling head and a Panchayat or a council composed by the Pramanikas ... These Samajas were in their respective spheres self-governing and representative, and worked by love ... blending the people as if in one body, making them respect the order and law ... Their leaders as also the king himself were completely under the control of the law and order.

This made the Kshatriyas "loving confederates with all other similar Samajas as also the rest of mankind." The letter advocated political organization under "the Sovereign power," and urged the British to revitalize this tradition of local governance, of which residues still remained, by fostering "self-governing and self-improving [atmashasani o atmotkarshi] Institutions," and establishing "village Communities and Panchayats" as "the basis of popular representation." Barma insisted that in government councils, "the representation must be thorough and every community, high or low, and every interest," especially "of the small communities or interests," should be given due regard. The Bengali equivalent of "law and order" was vidhi o shasanshrinkhala; but at one place, where the Bengali paraphrases the English, dharma encompassed the English terms "law and order," "virtuous," and "good." Ultimately, Barma noted, for the Samiti, "final emancipation of the souls [jivatmar vimukti-sadhan] by the finding of the great soul in all we see [drishyaman jagat madhye paramatmar darshan], is the goal." 43

Barma thus deployed a precolonial Indic metaphysical position, the visualization of the divine in all as the way to engineer a soul's liberation, to bolster the demand for non-majoritarian representative government. Across the 1910 s and 1920s, there was also a pervasive faith among Rajavamshi activists in unnati/progress, embedded in vidhinishedha (laws and prohibitions). This entailed shifts from an atomistically organized prakriti (nature), through prabhushasan (rule by master) and samajshasan (rule by society), to atmashasan (soul/self-rule, the same term used in Barma's 1917 letter as an equivalent of

\footnotetext{
${ }^{41}$ House of Commons, Parliamentary Papers, East India (Constitutional Reforms), Report on Indian Constitutional Reforms (1918), 5.

42 Kshatriya Samiti, San 1324 Saler Ashtam Varsher Vritta-vivaran (Rangpur, 1918), 50-55.

43 Ibid.
} 
the English "self-governing") and atmashakti (soul/self-power), culminating in salvation. Training in dharma, understood in terms of moral, ritual, social, and political laws, mediated this process, motivating the Rajavamshi to attain worldly and spiritual self-government. ${ }^{44}$ In 1927, in a celebrated speech before the Samiti, Barma equated the Rajavamshi/Kshatriya with divinity. As the divine, exemplified by Krishna, ensured dharma samsthapan (institution of dharma: Barma quoted the Gita here), so did the Kshatriya institute and protect dharma on earth: this also entailed atmashakti. ${ }^{45}$ The (idealized) Rajavamshi, as a legislating and law-protecting subject, replicated God's law-giving and law-maintaining function.

The interwar-era Rajavamshi demand for democratic representation was inflected by class and gender stratifications. Relatively better-off peasants were privileged over lower-class agriculturists; women's political, legal, and social rights were given less importance than those of men. ${ }^{46}$ Nevertheless, within a deeply stratified caste society, Rajavamshi politics innovated a putatively universalistic legal theology and soteriology, rooted in peasant desire for improved social status, political voice, literacy, and economic betterment. It operated, as Barma's 1917 letter noted, in collaboration with "the Sovereign power," looked to "the protecting power the King-Emperor," and hoped that "all the people of the British Empire can live in peace, prosperity and mutual love and respect." 47 The goal was to partially dehierarchize and indigenize the globespanning structures of imperial sovereignty, through the growth of representative legislative politics and legal systems of reservation for subalternized caste groups and other "minority" communities. In the process, Rajavamshi activists also produced materialistic critiques of exploitation of labor, and especially peasant labor. By the 1940s, Rajavamshis were among the most radicalized peasant communities in India. Rajavamshi women, as much as men, were at the forefront of the communist-influenced Tebhaga agrarian struggles. ${ }^{48}$ Ultimately, by theologizing legal concepts, Rajavamshi politicians connected universalistic

44 E.g. ibid., 7, 27-46; Kshatriya Samiti, Tritiya Varsher Vrittavivarani, Chaturtha Varsher Adhiveshan (Rangpur, 1913), 1, 8-14; Samiti, Navam Varsher arthat San 1325 Saler Vrittavivarani (Rangpur, 1919), 20-21, 49-59; Samiti, Ekadash Sammilani, Karyavivarani (Rangpur, 1919), 30-33; Samiti, Dasham Varshik Adhiveshan, Karya Vivaran (Rangpur, 1919), 47-53; Samiti, Chaturdash Varsher arthat San 1329 Saler Vrittavivaran (Rangpur, 1923), 2, 32-9; Samiti, Ashtadash Varshik Adhiveshan, Karya-vivaran (Rangpur, 1927), 925, 57-61.

45 Samiti, Ashtadash, 21-4.

46 Basu, Dynamics of a Caste Movement; and Barma, Indomitable Panchanan, highlight aspects of social hierarchy in Rajavamshi politics.

47 Samiti, San 1324, 51-2.

48 Basu, Dynamics of a Caste Movement; Banerjee, The Mortal God, chap. 4. 
categories of mankind/selfhood/atma/ jagat with communitarian articulations of identity, and prepared the ground for collectivist forms of peasant and lower-caste struggle.

\section{RADHABINOD PAL, RITA, AND INTERNATIONAL LAW}

Radhabinod Pal, the dissenting Indian judge at the Tokyo Trial (1946-8), is perhaps modern India's most celebrated international jurist, and widely regarded as a pioneer non-European critic of the imperial foundations of international law. Born in a poor "low-caste" (potter) family, he received his doctorate at the University of Calcutta and lectured there on law, including Hindu law. In 1941, he became judge in the Calcutta High Court, and in 1944 vice chancellor of the University of Calcutta. In the aftermath of Tokyo, he served in the International Law Commission $(1952-66)$, and was twice $(1958,1962)$ elected its chairman. ${ }^{49}$

While writing on Hindu law from the 1920s, Pal arranged Sanskrit texts according to a historicist schema, prioritizing Vedic (including Upanishadic) texts over later discourses on dharma/law. He felt that the Rigveda (second millennium BCE) was composed before the Brahmanical caste hierarchy had fully developed in India, whereas the later Manusmriti (late first millennium BCE/early first millennium CE) legitimated the oppression of lower castes and women. Pal blamed the lawgiver Manu, legendary author of the Manusmriti, for privileging sovereign power over justice. By 1958, and drawing upon Friedrich Nietzsche, Pal conceptualized race and caste as offering related frameworks of heredity-based exploitation of the common people..$^{5}$ More broadly, between the 1920 and 1950 , Pal came to conceptualize religious/premodern and non-religious/modern forms of governance as structurally similar in their shared dependence on a lawgiver's will. In a book on Hindu law published in 1927, he argued,

The earliest form in which it [the idea of authority] enters the arena is in that of a belief in a divinely ordained or divinely dictated body of rules; whilst in its latest form it is a dogma that law is a body of commands of the sovereign power in a politically organized society, resting ultimately on whatever might be the basis of that sovereignty. In either of these forms it puts a single ultimate unchallengeable author behind the

49 This section draws on Milinda Banerjee, "Does International Criminal Justice Require a Sovereign? Historicising Radhabinod Pal's Tokyo Judgment in Light of His 'Indian' Legal Philosophy," in Morten Bergsmo, Cheah Wui Ling, and Yi Ping, eds., Historical Origins of International Criminal Law, vol. 2 (Brussels, 2014), 67-117; and Banerjee, "Decolonization and Subaltern Sovereignty: India and the Tokyo Trial," in Kerstin von Lingen, ed., War Crimes Trials in the Wake of Decolonization and Cold War in Asia, 1945-1956 (London, 2016), 69-91. See these essays for detailed discussions on the historiography about Pal and the Tokyo Trial.

50 Banerjee, "International Criminal Justice," 72-86. 
legal order, as the source of every legal precept whose declared will is binding simply as such..$^{51}$

Later, in 1958, he observed, "There is little fundamental difference between the law viewed as the will of the dominant deity and the law viewed as the will of the dominant political or economic class. Both agree in viewing law as a manifestation of applied power." ${ }^{2}$ By discussing Jean Bodin, Thomas Hobbes, John Locke, Jean-Jacques Rousseau, and John Austin, Pal critiqued various forms of statehood and law by analyzing their dependence on a dominant sovereign's will. 53

To dissociate justice or law from sovereignty, Pal valorized, from the 1920s, the Rigvedic principle of rita as a concept of "natural and human order" that approximated Roman and Christian concepts of ratio, naturalis ratio, pax, lex aeterna, and ratio in Deo existens. ${ }^{54}$ Pal admired "Greek sages, Roman Philosophers and jurisconsults, and mediaeval thinkers of the natural law school" for stressing that law was "based on reason" and was "discoverable" by "the rational instinct in man." 55 Hence

the Vedic Rishis generally place law even above the divine Sovereign. The law according to them exists without the Sovereign, and above the Sovereign; and if an Austin or a [Max von] Seydel tell them that "there is no law without a sovereign, above the sovereign, or besides the sovereign, law exists only through the sovereign", they would not believe him. Nay, they would assert that there is a rule of law above the individual and the state, above the ruler and the ruled ... and if there is such a thing as sovereignty, divine or otherwise, it is limited by this rule of law. ${ }^{56}$

This supra-sovereign law needed to be functionalized through a socially responsive corpus of transformable human laws, exemplified, for Pal, by the Rigvedic vrata. ${ }^{57}$

Ironically, despite his critiques of sovereignty, in the Tokyo Trial Pal defended Japanese state sovereignty, and (many have argued) even offered an apologia for Japanese sovereign violence. His morally problematic dissent "acquitted of all those charges," of conventional war crimes, crimes against humanity, and

\footnotetext{
51 Radhabinod Pal, The Hindu Philosophy of Law in the Vedic and Post-Vedic Times Prior to the Institutes of Manu (Calcutta, 1927), 7.

52 Radhabinod Pal, The History of Hindu Law in the Vedic Age and in Post-Vedic Times Down to the Institutes of Manu (Calcutta, 1958), v.

53 Ibid., 2-6, 219-21.

54 Pal, The Hindu Philosophy of Law, 1-2 (quote), 52; Pal, History, iv, 109-10, 144.

55 Pal, The Hindu Philosophy of Law, 76; Pal, The History of Hindu Law, 160.

56 Pal, The Hindu Philosophy of Law, 72-3.

57 Ibid., 6-10, 55-60; Pal, The History of Hindu Law, 146-8.
} 
crimes against peace, "each and everyone of the accused." 58 Earlier scholars, focusing mostly on Pal's Tokyo dissent to the exclusion of his other writings (on Hindu law and global justice), have often tended to see him as someone who wished to protect, from a broadly positivistic stance, the Japanese state's claim to sovereignty, and the Japanese political-military leadership's claim to have the right to commit violence to protect their nation's supposed self-interest, against the demands of international criminal justice put forth by the prosecution and accepted by most of the judges representing the Allied Powers. (Interestingly, the prosecution relied on ideas of natural law to structure their legal philosophy. ${ }^{59}$ Others have detected traces of naturalist just-war idea (for anticolonial ends) in his dissent. ${ }^{60}$ The few scholars who have given attention to the writings on Hindu law have seen Pal as embodying an allegedly authentic Hindu-Indic legal-moral worldview, which supposedly stood in sharp contrast to Western ideas of justice. ${ }^{61}$ My own take on Pal, based on reading his different works in dialogue with each other, is to see him neither as a simple positivist, nor as a mere advocate of a Western type of just-war theory, nor as a champion of some primordial and unchanging Indic civilizational stance. Rather, I read Pal's dissent in Tokyo as embodying a fascinating double move, to both attack and preserve the idea of sovereignty. Pal admitted, "I, myself, am not in love with this national sovereignty," ${ }^{2}$ but adopted his stance since "the present age is faced with not only the menace of totalitarianism but also the actual plague of imperialism." He could not accept that the Allied Powers functioned like a divine lawgiver, as "a valiant god struggling to establish a real democratic order in the Universe." ${ }^{\prime 63} \mathrm{He}$ denied that the Allied Powers could claim to be "a sovereign of the international community. It is not the sovereign of that much desired superstate." ${ }^{64}$ Echoing

${ }_{58}$ International Military Tribunal for the Far East, The United States of America and Others v. Araki Sadao and Others, Judgment of The Hon'ble Mr. Justice Pal, Member from India, at www.legal-tools.org/en/go-to-database/ltfolder/o_29521, 1226.

59 E.g. Judith N. Shklar, Legalism: An Essay on Law, Morals and Politics (Cambridge, MA, 1964), 179-9o; Elizabeth S. Kopelman, "Ideology and International Law: The Dissent of the Indian Justice at the Tokyo War Crimes Trial," New York University Journal of International Law and Politics 23/2 (1990-91), 373-444; Yuma Totani, The Tokyo War Crimes Trial: The Pursuit of Justice in the Wake of World War II (Cambridge, MA, 2009), 218-62.

6o E.g. Kirsten Sellars, "Imperfect Justice at Nuremberg and Tokyo," European Journal of International Law 21/4 (2011), 1085-1102, at 1096; also Neil Boister and Robert Cryer, The Tokyo International Military Tribunal: A Reappraisal (Oxford, 2008), 285-91.

61 E.g. Ashis Nandy, “The Other Within: The Strange Case of Radhabinod Pal's Judgment on Culpability," New Literary History 23/1 (1992), 45-67; Barry Hill, "Reason and Lovelessness: Tagore, War Crimes, and Justice Pal," Postcolonial Studies 18/2 (2015), 145-60.

62 Pal judgment, 186.

63 Ibid., 239-40, original emphasis.

64 Ibid., 55. 
Bankimchandra's criticism of the "right of conquest," Pal stressed that "mere conquest, defeat and surrender, conditional or unconditional, do not vest the conqueror with any sovereignty of the defeated state." ${ }^{65}$ Fearing that the Allied Powers were seeking to use the trial to legitimate a new multistate order of imperial sovereignty in Asia, Pal strategically exculpated the Japanese leadership with the aim of protecting Japanese sovereignty. More broadly, Pal desired to defend non-European societies from "Western" conquest by expropriating Europeanorigin grammars of state sovereignty. He felt that violence by non-European actors, especially when directed toward protecting their societies' sovereignty, could thus be justified: I have elsewhere termed this posture "subaltern sovereignty." 66

This compromise with sovereignty, however, did not translate into an abandonment of the dream for global-and supra-sovereign-justice. Even in his Tokyo dissent, Pal hoped, quoting Hans Kelsen, that international criminal justice would in future be functionalized though impartial international tribunals and courts that would judge actors from victor and vanquished nations alike (unlike as in Tokyo). He affirmed, aligning with Hersch Lauterpacht, that "international law should recognise the individual as its ultimate subject and maintenance of his rights as its ultimate end." ${ }^{67}$ Between the late 1940 and the 1960s, Pal often fulminated against the "contempt and exploitation of coloured minorities living among white majorities, or of coloured majorities governed by minorities of white imperialists," against "racial hatred" and "hatred of the poor." He was shocked by the way in which "two-thirds of the World's population live in a permanent state of hunger," "in degrading poverty and primitive backwardness." ${ }^{68} \mathrm{Pal}$ was concerned about reimpositions of imperialism as well as struggles for decolonization in Asia and Africa (especially in Indonesia, Indochina, and Korea). Through his work in association with the International Law Commission, as well as his public speeches and writings, he sought to forge the vision of a new international legal order. ${ }^{69}$ This would emerge-he observed in a 1962 International Law Commission report about a legal committee meeting of (mostly newly independent) Asian and African states in Rangoon-through encounters between representatives of decolonizing societies who would converge to express "the popular will of the world," instigated by a "sense of injustice ... universally felt," and would forge new "legal provisions" which would help

\footnotetext{
65 Ibid., 6o-61.

66 Banerjee, "Decolonization and Subaltern Sovereignty."

67 Pal, judgment, 10-15, 145.

68 Pal, The History of Hindu Law, 269, 274.

69 Banerjee, "International Criminal Justice," 109-12.
} 
"build up world communal life."70 For Pal, this transformation had ethical and soteriological implications (which he worked out through extensive citations of Vedic and Upanishadic texts). ${ }^{71}$ As he summarized in his 1958 book on Hindu law, the quest for justice was driven by the recognition that "our fellow man ... by the very fact of its being a consciousness is sacred to our own." Hence notions of "right," including "rights of man' ... to life, liberty, and pursuit of happiness on equal terms with all," had to coexist with principles of "duty" to fellow human beings. $^{72}$

\section{CONCLUSION}

Sanjay Subrahmanyam has recently critiqued the project of global intellectual history for reinscribing Eurocentrism in the name of foregrounding the global. ${ }^{73}$ This essay shows that a braiding together of archives in multiple (including extraEuropean) conceptual and linguistic registers can help destabilize Eurocentric frames. When I speak about destabilizing Eurocentrism, I do not imply that we can or should recover some "authentic" native tradition that stands in complete difference from European concepts. For late nineteenth-/early to mid-twentiethcentury Indian actors, such a project would in any case be impossible to undertake, given the depth of their entanglement with European-origin ideas and practices of power. I call for something else. If we focus on the arguments advanced by the Bengali actors, we see that many of the battles they fought (for example against caste hierarchies) or the categories they drew on (for example "all beings") were deeply enmeshed within power struggles, argumentative forms, and ethical postures grounded in South Asian contexts of precolonial as much as of colonial origin. To destabilize Eurocentrism does not imply exiling Europe from discussion in nativist retaliation. It implies taking battles fought, and concepts produced, in other corners of the world, including in centuries long past, with equal seriousness as generative of contemporary (here especially legal) thought. In our historical gaze, we need to intersect the transregional with the transtemporal. We need to recognize that the crossroads we study-where, at a given point, arguments of distanced spatial and temporal origin can gather together to stimulate a new thought, by reinforcing, contradicting, and transforming each other-are

7o Radhabinod Pal, Report on the Fifth Session of the Asian-African Legal Consultative Committee (Rangoon, January 1962), 153-4, at http://legal.un.org/docs/?path=../ilc/ documentation/english/a_cn4_146.pdf\&lang=EFS, accessed 24 Jan. 2017.

71 Banerjee, "International Criminal Justice," 83-5, 116-17.

72 Pal, The History of Hindu Law, 171-2, 282.

73 Sanjay Subrahmanyam, "Global Intellectual History beyond Hegel and Marx," History and Theory 54/1 (2015), 126-37. 
constitutive of discourse (rather than being add-on citations of instrumentalist convenience).

A frame of "Europe mixing with non-Europe," or "non-Europe fulfilling Europe" (truncated universalism), may be interpretively helpful to a limited extent in this regard (for example, in understanding why some of Bankimchandra's arguments resemble Carl Schmitt's, in terms of thinking about a divine lawgiver). But a mere focus on mixing of ideas cannot by itself adequately explain the deep structural force of new forms of thought produced by the actors, and the ways in which such thinking compels actors to take powerful positions, often under conditions of duress. To address this inadequacy, I build on Samuel Moyn's reflection about "finding the right compromise between the 'logic' of concepts and the contingencies of their spread." ${ }^{4}$ I point to a certain global "logic" of sovereignty that was accepted by the Bengali actors to formulate their discourses on political autonomy and law, and to advance various anticolonial, nationalist, and/or communitarian agendas. But logics often exist in dialectical tension with counterlogics. The Bengali actors complicated regimes of sovereignty, statehood, and legality in the name of categories like "all beings," "humanity," "mankind," "self/soul," and "world," as well as with reference to specific geographies and figures: Native Americans, Rajavamshis, scheduled castes, peasants, British Empire, Japan, Hersch Lauterpacht, and so on. They drew on precolonial-origin Indian arguments about the theological identity of all selves, about their mutual obligations, and about a higher sacralmoral law (rita, dharma), while also citing modern scientific interpretations of laws of nature. They gave rise to variegated forms of social collectivity and political solidarity, and propelled new modes of organizational struggle with uneven social reach (in terms of race/ethnicity, class, and sex). Owing to such argumentations, the morphologies of statehood remained open to contestation, within India, for example in the legal-constitutional format of reservations for socioeconomically disempowered scheduled castes and scheduled tribes, as well as in international forums like the United Nations, where the dissolution of European empires and the emergence of postcolonial states was debated across the 1950 s and 1960 s with increasing clamour. (For South Asia, controversies surrounding India's militant action to end Portuguese rule over Goa and take control of the region in 1961 well exemplify this reshaping of state geographies, justified in part through debates about international law in international organizations. Kirsten Sellars has underlined the appeals to higher-naturalism-inflected-justice made during the Goa case as well as, more generally, in support of anticolonial insurrections in this era. ${ }^{75}$ ) These legal-conceptual interventions thus became part of wider

\footnotetext{
74 Moyn, "On the Nonglobalization of Ideas," 201.

75 Kirsten Sellars, "Crimes against Peace" and International Law (Cambridge, 2013), 272-6.
} 
histories of decolonization and democratization. The ethical-political choices exercised by actors thus have methodological primacy for my study, while dialectically coexisting with globally spanning "logics."

Indeed, legal intellection offers a preeminent location for studying this kind of dialectic. After all, it is not only the case that "law is a ... manifestation of crystallized power, ${ }^{\prime 6}$ but also, very specifically, the crystallization of power into concept, and further into concept which operates across the contradictions of is and ought. Legal concepts-including concepts like dharma and natural law-render legible exercises of mastery. Simultaneously, legal-discursive work opens up avenues for resistance, solidarity, and intractable justice. Legal concepts and arguments offer the intellectual interfaces par excellence in the dialectics of mastery and (in)subordination. By focusing on debates about sovereignty, we can thus broach questions, with planetary valence, about the relation between varied forms of authority and conceptions of transcendence, the latter offering ground that sanctions and anchors mastery as law, as well as the ground for critiquing law and mastery in the name of justice.

Hence the peculiar salience of legal-political theology to global intellectual history. The global spread of modern formats of state sovereignty and law was coeval with the rise of globally entangled understandings of divinity and divine (lawgiving) sovereignty: these processes indeed reinforced each other. Thus the Bengali actors I study and Carl Schmitt arrived at similar understandings of political-legal theology—about the relation between monistic constructions of sovereignty and legalistic constructions of divinity—even though they had never read each other. But the planetary spread of modern regimes of state sovereignty, and associated explosion of sovereign—often racial-imperial—violence, also provoked new theologically inflected imaginings of the global, which redefined law not as the will of a superordinate and authoritarian sovereign, but as the product of the responsibility one has to other beings, conceptualized in their existentiality as sacred or divine. Such arguments mapped the divine or the transcendental in relation to law in ways which differed markedly from Schmitt. (In this sense, my discussion on legal theology also brackets and provincializes Schmitt instead of venerating him as the encompassing interpretive keystone.) It would be fruitful to track the multisited emergence of such views across the late nineteenth and the twentieth centuries. One could compare European intellectuals who produced novel ideas of self-other relation, or even about the sacredness of the other, in part as reactions to authoritarian regimes and statesponsored violence-Emmanuel Levinas (1906-95) is exemplary-with South Asian intellectuals who produced parallel perspectives while battling the violence

76 Nathan Rotenstreich, Order and Might (Albany, 1988), 42. 
and authoritarianism enforced and instigated by the colonial state (in complicity with indigenous actors). It would be interesting to analyze the emergence of new notions of justice and revolutionary collectivity as actors shift the weight of ethical commitment and political legitimacy from the legal-political sovereign to subalternized Others: a process which is by no means yet complete. 